\title{
ARE DIPLOMATIC ASSURANCES ADEQUATE GUARANTEES OF SAFETY AGAINST TORTURE AND ILL-TREATMENT? THE PRAGMATIC APPROACH OF THE STRASBOURG COURT
}

\author{
Aristi Volou*
}

\begin{abstract}
The use of diplomatic assurances against torture and other ill-treatment has increased in recent years in response to the continued growth of international terrorism. However, this practice is controversial because it engages the Contracting States' obligation not to extradite or expel a person where there are substantial grounds for believing that he or she would face a real risk of being subjected to treatment contrary to Article 3 ECHR in the receiving State. The Strasbourg Court's pragmatic approach suggests that in certain circumstances, following an analysis of the quality of the assurances and their practical effect, diplomatic assurances can be adequate guarantees of safety. As a result, it will be argued that the Strasbourg Court cannot be accused of circumventing the absolute prohibition found in Article 3 ECHR by accepting the diplomatic assurances policy of the Contracting States. The author will conclude by arguing that the Strasbourg Court's approach is effective as it reinforces the absoluteness of Article 3 ECHR while at the same time allowing States to protect their national security from terrorism.
\end{abstract}

\section{A. INTRODUCTION}

This paper will examine the approach of the European Court of Human Rights (the Court/the Strasbourg Court) to diplomatic assurances against torture and other ill-treatment. The first part of the paper will focus on the absolute nature of Article 3 European Convention on Human Rights (ECHR/the Convention) and its extraterritorial effect. The ruling of the Strasbourg Court on the extraterritorial nature of Article 3 ECHR was not generally welcomed by the Contracting States and it was against this background that the Court has, in certain circumstances, accepted States' use of diplomatic assurances. This acceptance has been criticised, however, for circumventing the absolute prohibition of torture and other illtreatment on the basis that diplomatic assurances are inherently unreliable, as the second part of the paper will explore. However, the last part of the paper will demonstrate that the Court has managed to combat these criticisms by taking a pragmatic approach to diplomatic assurances. The Court assesses the reliability of the assurances based on their quality and their ability to eliminate the risk of torture and ill-treatment in practice. It considers these factors on a case-by-case basis and in light of all the circumstances of the case before it. Against this background, it can be argued that the assurances that have been accepted by the Strasbourg Court are effective guarantees against subjection to the proscribed treatment. As a

\footnotetext{
* PhD student in Law, University of Leicester. I am grateful to Professor Liz Wicks for her invaluable assistance.
} 
result, the paper will argue that the Court cannot be accused of circumventing the absolute prohibition to be found in Article 3 ECHR by accepting the use of diplomatic assurances by the Contracting States. Its approach, as the author will maintain, upholds the absolute nature of Article 3 ECHR and at the same time it allows States to protect their national security.

\section{B. THE ABSOLUTE NATURE AND THE EXTRATERRITORIAL EFFECT OF ARTICLE 3 ECHR}

The main aim of this section is to examine the extraterritorial effect of Article 3 ECHR. This analysis is essential for the purposes of this paper as the issue of diplomatic assurances arises in cases which concern the extraterritorial effect of Article 3 ECHR. Given also that the nature of Article 3 ECHR is said to be compromised when assurances are used, it is necessary to look at the question of what absoluteness means in this context.

\section{The absolute nature of Article $3 \mathrm{ECHR}$}

The most important feature of Article 3 ECHR concerns its nature. As the Strasbourg Court has stressed, 'the Convention prohibits in absolute terms torture or inhuman or degrading treatment or punishment'. ${ }^{1}$ Unlike most of the substantive Articles of the Convention and of Protocols 1 and 4 to it, Article 3 ECHR makes no provision for exceptions. ${ }^{2}$ Article 3 ECHR is also non-derogable. ${ }^{3}$ While Article 15 ECHR permits the Contracting States to derogate from their obligations under the Convention in respect of the majority of the Articles '[i]n time of war or other public emergency threatening the life of the nation', there is no provision for derogation from Article 3 ECHR. ${ }^{4}$ It is therefore clear that diplomatic assurances must be reliable if they are to be used in the context of Article 3 ECHR. Otherwise, their use will undermine the absolute nature of this provision.

\section{The extraterritorial effect of Article $3 \mathrm{ECHR}$}

It is in the landmark case of Soering $v$ the United Kingdom that the Strasbourg Court held that Article 3 ECHR can have an extraterritorial effect, ${ }^{5}$ in that Contracting States might be liable for acts that occur outside their jurisdiction. ${ }^{6}$ This case concerned Jens Soering, a German fugitive, whose extradition from the United Kingdom was requested by the Government of

\footnotetext{
${ }^{1}$ Chahal v United Kingdom App no 22414/93 (ECtHR, 15 November 1996) para 79.

${ }^{2}$ PJ Duffy, 'Article 3 of the European Convention on Human Rights' (1983) 32 ICLQ 316, 321; Chahal (n 1) para 79.

${ }^{3}$ Convention for the Protection of Human Rights and Fundamental Freedoms (European Convention on Human Rights, as amended) (ECHR) art 15(2); Chahal (n 1) para 79.

${ }^{4}$ ECHR art 15(1).

${ }^{5}$ Soering $v$ the United Kingdom App no 14038/88 (ECtHR, 7 July 1989) para 91; Hélène Lambert, 'Protection against Refoulement from Europe: Human Rights Law Comes to the Rescue' (1999) 48 ICLQ 515, 527.

${ }^{6}$ Al-Skeini and others $v$ the United Kingdom App no 55721/07 (ECtHR, 7 July 2011) para 131.
} 
Are Diplomatic Assurances Adequate Guarantees of Safety Against Torture and IllTreatment? The Pragmatic Approach of the Strasbourg Court

the United States of America on two counts of capital murder. ${ }^{7}$ Soering filed an application against the United Kingdom Government, inter alia, under Article 3 ECHR. ${ }^{8}$ He alleged that if he was to be extradited to the United States of America, there was a serious likelihood of being sentenced to death. ${ }^{9}$ He argued that exposure to the 'death-row phenomenon' would amount to being subjected to inhuman and degrading treatment and punishment contrary to Article 3 ECHR. ${ }^{10}$

The Strasbourg Court held that extraditing a person would give rise to liability under Article 3 ECHR where substantial grounds were shown for believing that the person concerned, if extradited, faced a real risk of being subjected to torture or other ill-treatment in the requesting country. ${ }^{11}$ The Court made clear that in such cases it is the responsibility of the sending Contracting State that is at issue and not that of the receiving State. ${ }^{12}$ This is because, the former has taken action 'which has as a direct consequence the exposure of an individual to proscribed ill-treatment'. ${ }^{13}$ The Strasbourg Court in applying this test on Soering's circumstances concluded that his removal would constitute a breach of Article 3 ECHR. ${ }^{14}$

a) The requirements of the Soering test

The Court will assess whether there are 'substantial grounds' for believing that the person concerned faces a real risk of being subjected to treatment contrary to Article 3 ECHR in the light of all the material placed before it or material obtained of its own motion. ${ }^{15}$ As regards the time at which the risk to the applicant should be assessed, the Strasbourg Court has repeatedly stated that in cases where the extradition or expulsion has not yet taken place 'the material point in time is that of the Court's consideration of the case'. ${ }^{16}$ In cases where the extradition or expulsion has already occurred 'the existence of the risk must be assessed primarily with reference to those facts which were known or ought to have been known to the Contracting State at the time of the expulsion'. ${ }^{17}$ However, 'the Court is not precluded (...) from having regard to information which comes to light subsequent to the expulsion' ${ }^{18}$

\footnotetext{
${ }^{7}$ Soering (n 5) paras 11-12.

8 ibid para 76.

${ }^{9}$ ibid.

${ }^{10}$ ibid.

${ }^{11}$ Ibid para 91.

12 ibid.

13 ibid.

14 ibid para 99.

${ }^{15}$ Cruz Varas and others $v$ Sweden App no 15576/89 (ECtHR, 20 March 1991) para 75.

${ }^{16}$ Venkadajalasarma $v$ the Netherlands App no 58510/00 (ECtHR, 17 February 2004) para 63; Ahmed v Austria App no 25964/94 (ECtHR, 17 December 1996) para 43.

17 Cruz Varas (n 15) para 76; Vilvarajah and others $v$ the United Kingdom App no 13163/87; 13164/87; 13165/87; 13447/87; 13448/87 (ECtHR, 30 October 1991) para 107.

18 ibid.
} 
As regards the standard of proof, the Strasbourg Court is satisfied that the risk of illtreatment is 'real' only when the foreseeable consequence of the Contracting State's decision to extradite or expel the individual in issue is that he or she will be subjected to treatment contrary to Article 3 ECHR in the receiving State. ${ }^{19}$ Even though the Court has never given a clear definition of the standard of proof, in the case of Vilvarajah and others $v$ the United Kingdom it clarified that ' $[\mathrm{a}]$ mere possibility of ill-treatment (...) is not (...) sufficient to give rise to a breach of Article 3'. ${ }^{20}$ This statement can be taken, as Hemme Battjes has observed, as a negative definition of the standard of proof 'in the sense that real risk is more than that'. ${ }^{21}$

The Strasbourg Court, in examining the foreseeable consequences of the Contracting State's decision to extradite or expel the applicant, takes into account a number of factors. The first is the general situation in the receiving State. ${ }^{22}$ This was considered by the Court in Sufi and Elmi v the United Kingdom. ${ }^{23}$ The Court held that their removal to Mogadishu would breach Article 3 ECHR as the level of violence there 'was of sufficient intensity to pose a real risk of treatment reaching the Article 3 threshold to anyone in the capital' ${ }^{24}$ The Court will also consider the applicant's personal situation. ${ }^{25}$ Gaforov v Russia is illustrative on this point. ${ }^{26}$ One of the factors that was taken into account by the Court in concluding that substantial grounds had been shown for believing that the applicant would face a real risk of treatment proscribed by Article 3 ECHR, if extradited to Tajikistan, was the personal situation of the applicant. ${ }^{27}$ Specifically, the Court took account of the fact that Gaforov was wanted by the Tajikistani authorities on account of his alleged participation in a transnational Islamic organisation and of the fact that supporters of this organisation were persecuted in Tajikistan. $^{28}$

In the noteworthy case of Othman (Abu Qatada) $v$ the United Kingdom, the Strasbourg Court took into account a further factor, which is the focus of this paper. ${ }^{29}$ In that case, which concerned the planned expulsion of a Jordanian national to Jordan on grounds of

\footnotetext{
${ }^{19}$ Soering (n 5) para 90.

${ }^{20}$ Vilvarajah (n 17) para 111.

${ }^{21}$ Hemme Battjes, 'In Search of a Fair Balance: The Absolute Character of the Prohibition of Refoulement under Article 3 ECHR Reassessed' (2009) 22 LJIL 583, 609.

${ }^{22}$ Sufi and Elmi v the United Kingdom Apps nos 8319/07 and 11449/07 (ECtHR, 28 June 2011) para 219.

23 ibid.

24 ibid paras 250, 248.

${ }^{25}$ Gaforov v Russia App no 25404/09 (ECtHR, 21 October 2010) para 132.

${ }^{26}$ ibid.

${ }^{27}$ ibid 139, 132.

28 ibid paras $132,134$.

${ }^{29}$ Othman (Abu Qatada) v the United Kingdom App no 8139/09 (ECtHR, 17 January 2012) para 187.
} 
Are Diplomatic Assurances Adequate Guarantees of Safety Against Torture and IllTreatment? The Pragmatic Approach of the Strasbourg Court

national security, the Court found that the applicant's expulsion would not be in violation of Article 3 ECHR since the United Kingdom Government obtained assurances from the Jordanian authorities that were sufficient to remove any real risk of ill-treatment. ${ }^{30}$ Thus, the issue of diplomatic assurances becomes relevant when the Strasbourg Court examines whether there exists a real risk for the applicant of being subjected to treatment contrary to Article 3 ECHR upon return. ${ }^{31}$

b) Assessing the ruling on the extraterritorial effect of Article 3 ECHR - diplomatic assurances as a pragmatic response

The decision of the Strasbourg Court that Article 3 ECHR has an extraterritorial effect can be criticised principally on two grounds. Firstly, it can be argued that since it is within the jurisdiction of the receiving State that the violation is anticipated to occur, the Contracting States have no responsibility whatsoever for this and it is therefore unfair to render them liable. ${ }^{32}$ This argument was put forward by the United Kingdom Government in Soering. ${ }^{33}$ Specifically, they contended that Article 3 ECHR should not impose responsibility on a Contracting State for acts which occur outside its jurisdiction. ${ }^{34}$ However, the Court concluded that such a consideration 'cannot (...) absolve the Contracting Parties from responsibility under Article 3 (...) for all and any foreseeable consequences of extradition suffered outside their jurisdiction'. ${ }^{35}$ Given that Article 3 ECHR enshrines one of the most fundamental values of democratic society, the serious and irreparable nature of torture and illtreatment and the absolute nature of Article 3 ECHR, the Court could reach no other conclusion. ${ }^{36}$

Second, it might be argued that the Soering decision has a potentially negative impact on the national security of the Contracting States. The Court, by placing restrictions on the ability of the Contracting States to extradite and expel dangerous criminals has, according to the United Kingdom Government in Soering, obliged the Contracting States to harbour criminals at the expense of their national security. ${ }^{37}$ The Court's approach is indeed very strict, as it disregards the legitimate national security concerns of the Contracting States which have increased, especially in recent years, due to the continued growth of international

\footnotetext{
${ }^{30}$ ibid paras 7, 25, 194-205.

31 ibid para 187.

32 Christine Van den Wyngaert, 'Applying the European Convention on Human Rights to Extradition: Opening Pandora's Box?' (1990) 39 ICLQ 757, 759-760.

${ }^{33}$ Soering (n 5) para 83.

${ }^{34}$ ibid.

${ }^{35}$ ibid para 86.

36 ibid paras $88,90$.

37 ibid para 83 .
} 
terrorism. In their attempts to combat terrorism and to protect their national security, several Contracting States, foremost among them the United Kingdom, have attempted to persuade the Court that these considerations should be taken into account in deciding whether to remove a person. ${ }^{38}$ Despite these 'strong assertions of national security considerations that have been presented by some European States', the Court 'has kept faith with the absolute nature of the prohibition to be found in Article 3, ${ }^{39}$ The Court in reaffirming its view - that Article 3 ECHR enshrines one of the most fundamental values of democratic society - has repeatedly stated that the Convention, even in these circumstances, prohibits in absolute terms torture and other ill-treatment. ${ }^{40}$

However, the Court, possibly as an acknowledgment of its unfair and strict approach, has accepted that Contracting States can enforce expulsions and extraditions without being liable under the Convention when they obtain sufficient assurances from the authorities of the receiving States to the effect that the persons concerned will not be subjected to the proscribed treatment upon return. ${ }^{41}$ Hence, the Court's acceptance of the diplomatic assurances policy can be seen as a pragmatic response to these criticisms.

\section{THE STRASBOURG COURT'S APPROACH TO DIPLOMATIC ASSURANCES AGAINST TORTURE AND ILL-TREATMENT: GENERAL PRINCIPLES AND CRITICISMS}

\section{General principles - Saadi v Italy}

Although the Strasbourg Court had reviewed cases involving diplomatic assurances against torture and other ill-treatment prior to 2008, it was the landmark case of Saadi v Italy in which the Court set out the principles that guide its current approach to them. ${ }^{42}$ The case of Saadi $v$ Italy concerned a Tunisian national who was arrested in Italy on suspicion of involvement in, inter alia, international terrorism. ${ }^{43}$ Though not convicted of any terrorist offences in Italy, he was convicted in absentia of terrorist offences by a military court in

\footnotetext{
${ }^{38}$ Chahal (n 1) para 76; Ramzy v the Netherlands (dec) App no 25424/05 (ECtHR, 27 May 2008) para 130; Saadi v Italy App no 37201/06 (ECtHR, 28 February 2008) paras 114, 122.

39 Jens Vedsted-Hansen, 'The European Convention on Human Rights, Counter-Terrorism, and Refugee Protection' (2011) 29 Refugee Survey Quarterly 45, 56; Robin CA White and Clare Ovey, The European Convention on Human Rights (5th edn, OUP 2010) 194.

${ }^{40}$ Chahal (n 1) para 79; Shamayev and others v Georgia and Russia App no 36378/02 (ECtHR, 12 April 2005) para 335.

${ }^{41}$ Othman (n 29) para 187.

${ }^{42}$ Alice Izumo, 'Diplomatic Assurances against Torture and Ill Treatment: European Court of Human Rights Jurisprudence' (2010) 42 Colum Hum Rts L Rev 233, 256; Soering (n 5) paras 97-98; Chahal (n 1) para 105.

${ }^{43}$ Saadi (n 38) para 11.
} 
Are Diplomatic Assurances Adequate Guarantees of Safety Against Torture and IllTreatment? The Pragmatic Approach of the Strasbourg Court

Tunis. ${ }^{44}$ Italy ordered his expulsion to Tunisia on the grounds of national security and the international fight against terrorism. ${ }^{45}$ In doing so, the Italian authorities requested from the Tunisian Government diplomatic assurances that if the applicant were to be expelled to Tunisia he would not be subjected to treatment contrary to Article 3 ECHR. ${ }^{46}$ In the first note verbale, the Tunisian Government merely stated that it was prepared to 'accept the transfer to Tunisia of Tunisians imprisoned abroad (...) in strict conformity with the national legislation in force and under the sole safeguard of the relevant Tunisian statutes' ${ }^{47}$ In a second note verbale, the Tunisian Government confirmed that 'the Tunisian laws in force guarantee and protect the rights of prisoners in Tunisia' and that 'Tunisia has voluntarily acceded to the relevant international treaties and conventions' ${ }^{48}$

The Strasbourg Court, at first, considered the quality of the assurances given and in particular, their content. It concluded that Tunisia's assurances were insufficient because they were general and vague, they lacked explicit guarantees against ill-treatment, they made no reference at all to the protection of the applicant from the proscribed treatment, and they failed to specify the relevant international treaties and conventions. ${ }^{49}$ However, the Court then made clear that even the existence of specific and explicit assurances would not be sufficient to ensure adequate protection against the risk of ill-treatment. ${ }^{50}$ Specifically, the Court stated that even if the Tunisian authorities had given the assurances that Italy had asked for, 'that would not have absolved the Court from the obligation to examine whether such assurances provided, in their practical application, a sufficient guarantee that the applicant would be protected against the risk of treatment prohibited by the Convention'. 51

In considering whether the assurances in issue provided, in their practical application, a sufficient guarantee of safety against the risk of ill-treatment, the Court paid due regard to the general situation in the receiving State. ${ }^{52}$ The Court in considering the human rights situation in Tunisia concluded that:

the existence of domestic laws and accession to international treaties guaranteeing respect for fundamental rights in principle are not in themselves sufficient to ensure adequate protection against the risk of ill-treatment where, as in the present case,

\footnotetext{
44 ibid paras 14, 29.

${ }^{45}$ ibid para 32.

46 ibid paras 51-52.

47 ibid para 54.

48 ibid para 55.

49 ibid para 147; Izumo (n 42) 257.

${ }^{50}$ Saadi (n 38) para 148.

51 ibid.

52 ibid para 147.
} 
reliable sources have reported practices resorted to or tolerated by the authorities which are manifestly contrary to the principles of the Convention. ${ }^{53}$

In considering these factors and the human rights record of Tunisia, the Strasbourg Court concluded that the risk of ill-treatment was not displaced by the assurances in issue. ${ }^{54}$ As a result, the Court held that substantial grounds had been shown for believing that Saadi ran a real risk of being subjected to treatment prohibited by Article 3 ECHR upon return to Tunisia and hence, that his expulsion would, if implemented, constitute a breach of Article 3 ECHR. ${ }^{55}$

\section{Assessing the Strasbourg Court's approach to assurances against torture and ill-} treatment

What emerges from the Strasbourg Court's approach in the case of Saadi is that the Contracting States cannot satisfy their Article 3 ECHR obligations by merely obtaining specific and explicit assurances from the authorities of the receiving States that the applicants will not be subjected to the proscribed treatment. To put it in another way, what emerges from the Court's approach in the case of Saadi is that 'the mere fact of an assurance is no answer to the [C]ourt's inquiry as to risk'. ${ }^{56}$ The Strasbourg Court in Saadi made it clear that in examining the foreseeable consequences of the Contracting State's decision to extradite or expel the applicant, it will take into account not only the existence of an assurance, but also the general situation in the receiving State. ${ }^{57}$ Thus, the existence of an assurance, although an important factor which is considered by the Court, is just 'one piece of this assessment' ${ }^{58}$ It would be surprising if the Court considered solely the existence of an assurance in examining the foreseeable consequences of the planned removal, especially when, as in the case of Saadi, reliable sources report widespread use of torture in the receiving State. ${ }^{59}$

In addition, the Court's approach in the case of Saadi suggests that it is the general situation in the receiving State that is determinative in assessing whether an applicant faces a real risk of ill-treatment and not the existence of an assurance. ${ }^{60}$ Therefore, in cases such as Saadi, where there is strong evidence by reliable sources that describes a disturbing situation in the country of destination, the existence of an assurance will carry little weight. In Saadi, for example, the assurances did not and would not, even if they were explicit and specific,

\footnotetext{
53 ibid.

54 ibid para 149.

55 ibid paras 146,149

${ }^{56}$ Eric Metcalfe, 'The False Promise of Assurances against Torture' (2009) 6(1) Justice 63, 74.

${ }^{57}$ Saadi (n 38) para 143.

${ }^{58}$ Izumo (n 42) 258.

${ }^{59}$ Saadi (n 38) para 143.

60 ibid para 147.
} 
Are Diplomatic Assurances Adequate Guarantees of Safety Against Torture and IllTreatment? The Pragmatic Approach of the Strasbourg Court

trump the other evidence. ${ }^{61}$ The Court also emphasised that diplomatic assurances would be deemed sufficient only in situations where they provide, in their practical application, effective protection against the risk of ill-treatment, demonstrating in this way that is the practical effect of the assurances rather than the text of the assurances which matters most. ${ }^{62}$ In this way, the Court made clear that it would 'look beyond the word of the receiving State'; in other words, its assurances; and that it would examine its actions. ${ }^{63}$

The Court correctly concluded that it would deem as insufficient the assurances given when, as in the case of Saadi, reliable sources report that the authorities of the receiving State routinely use torture and that they are unwilling to investigate incidents of torture. ${ }^{64}$ This conclusion of the Court is to be welcomed as, against this background, the assurances given by the Tunisian authorities were essentially empty promises and would not have protected Saadi against the risk of ill-treatment. Overall, the approach of the Court in the case of Saadi suggests that in certain circumstances, even if these circumstances are limited, it may consider diplomatic assurances to be a sufficient guarantee against the risk of ill-treatment' ${ }^{65}$

The Court's acceptance of this policy has not been welcomed however. The use of diplomatic assurances has been strongly criticised for circumventing the absolute prohibition of torture and other ill-treatment, given that, according to their opponents, assurances are unreliable, and therefore inadequate guarantees of safety against torture and ill-treatment. ${ }^{66}$ The Council of Europe's former Commissioner for Human Rights, for example, has argued that it is wrong to subject anyone to the risk of torture on the basis of a weak and informal undertaking. ${ }^{67}$ This hostility towards reliance on diplomatic assurances, on the ground that they are ineffective in practice is not unjustified, given that assurances have proved to be insufficient guarantees of safety in the past. ${ }^{68}$ This was demonstrated by the notorious cases of Ahmed Hussein Mustafa Kamil Agiza v Sweden and Mohammed Alzery v Sweden. ${ }^{69}$

\footnotetext{
61 ibid paras 147-148; Izumo (n 42) 258.

${ }^{62}$ Saadi (n 38) para 148.

${ }^{63}$ Izumo (n 42) 258.

${ }^{64}$ Saadi (n 38) para 147.

${ }^{65}$ Fiona de Londras, 'International Decision: Saadi v Italy' (2008) 102 AJIL 616, 620; Daniel Moeckli, 'Saadi v Italy: The Rules of the Game Have Not Changed' (2008) 8 HRLR 534, 546.

${ }^{66}$ See eg European Committee for the Prevention of Torture, cited in Nuala Mole, Asylum and the European Convention on Human Rights (4th edn, Council of Europe Publishing 2007) 42.

${ }^{67}$ Council of Europe Commissioner for Human Rights, cited in Mole (n 66) 42.

${ }^{68}$ Kate Jones, 'Deportations with Assurances: Addressing Key Criticisms' (2008) 57 ICLQ 183, 186.

${ }^{69}$ Ahmed Hussein Mustafa Kamil Agiza v Sweden CAT/C/34/D/233/2003 (24 May 2005); Mohammed Alzery $v$ Sweden CCPR/C/88/D/1416/2005 (10 November 2006).
} 
The former case concerned the expulsion of an asylum-seeker from Sweden to Egypt on suspicion of involvement in terrorist activities. ${ }^{70}$ The United Nations Committee Against Torture (CAT) found that the assurances obtained by the Swedish Government from the Egyptian authorities were not sufficient to protect the individual in issue from the proscribed treatment, as the applicant had been tortured in Egypt. ${ }^{71}$ In the latter case, Sweden expelled Alzery to Egypt in reliance on assurances of humane treatment. ${ }^{72}$ The United Nations Human Rights Committee (HRC) likewise found that the assurances were not sufficient to protect the applicant as the applicant had also been subjected to the proscribed treatment in Egypt. ${ }^{73}$ As a result of these cases, human rights organisations (particularly Human Rights Watch and Amnesty International), human rights advocates (such as Thomas Hammarberg) and academics (such as Lena Skoglund) have opposed the use of diplomatic assurances on the basis that they are unreliable. ${ }^{74}$ Human Rights Watch, for example, has claimed that these cases provide 'the clearest illustration to date of the inherently flawed nature of diplomatic assurances' and thus, that they should never be relied upon. ${ }^{75}$

Concerns about the use of assurances are, to some extent, therefore justified. However, this does not mean that diplomatic assurances are per se ineffective and that they should never be relied upon. Even though these cases have proved that diplomatic assurances may be sometimes ineffective, we should not, as Kate Jones has pointed out, 'deduce from such examples a general proposition that assurances against torture are all inherently unreliable'. ${ }^{76}$ This is demonstrated by the fact that the assurances that were accepted by Sweden as adequate guarantees in these two cases did not meet some minimum standards of reliability.

In the case of Agiza, the CAT found that as a result of Egypt's reputation in using torture against detainees held for political and security reasons, Sweden knew or should have known at the time of the applicant's removal that he would be at real risk of being subjected

\footnotetext{
${ }^{70}$ Agiza (n 69) paras 2.4-2.5.

71 ibid para 13.4.

${ }^{72}$ Alzery (n 69) paras 3.7, 3.9.

${ }^{73}$ ibid paras $10.5,11.5$.

${ }^{74}$ Human Rights Watch, 'Still at Risk: Diplomatic Assurances No Safeguard against Torture' (2005) 3 available at <http://www.hrw.org/sites/default/files/reports/eca0405.pdf> accessed 1 September 2014; Amnesty International, 'Dangerous Deals: Europe's Reliance on "Diplomatic Assurances" against Torture' (2010) 8 available at <http://www.amnesty.org/en/library/asset/EUR01/012/2010/en/608f128b-9eac-4e2f-b73b6d747a8cbaed/eur010122010en.pdf> accessed 1 September 2014; Council of Europe Commissioner for Human Rights, cited in Mole (n 66) 42; Lena Skoglund, 'Diplomatic Assurances against Torture - An Effective Strategy?' (2008) 77 NJIL 319, 362.

${ }^{75}$ Human Rights Watch (n 74) 57.

${ }^{76}$ Jones (n 68) 186.
} 
Are Diplomatic Assurances Adequate Guarantees of Safety Against Torture and IllTreatment? The Pragmatic Approach of the Strasbourg Court

to torture. ${ }^{77}$ Against this background, the 'procurement of diplomatic assurances, which, moreover, provided no mechanism for their enforcement, did not suffice to protect against this manifest risk'. ${ }^{78}$ As regards the case of Alzery, the HRC likewise found that the assurances obtained by the Egyptian authorities were not sufficient to protect the applicant as they did not provide for enforcement mechanism nor were there any other external arrangements that would have provided for effective implementation of the assurances. ${ }^{79}$ As a result, the HRC held that Sweden had failed to show that the diplomatic assurances were sufficient to eliminate the risk of ill-treatment. ${ }^{80}$ Therefore, the assurances that were accepted by Sweden failed to meet some minimum standards. Firstly, they could not in practical terms eliminate the serious risk of torture and second, they did not contain mechanisms for monitoring their enforcement. As a result, these cases cannot be used as a proof that diplomatic assurances are per se unreliable. What these cases teach us is that diplomatic assurances should be treated with caution. They should be subjected to a thorough examination and should meet certain minimum standards before one may conclude that they can be relied upon.

This is, in essence, the approach that the Strasbourg Court adopts. The Court does not seem to agree with the absolute and prejudiced opinion of the majority that assurances are per se ineffective and, should therefore never be relied upon. Rather, the approach of the Court in Saadi suggests that in certain circumstances diplomatic assurances can be regarded as a sufficient guarantee of safety. They can be regarded as a sufficient guarantee when, after careful examination, they appear to fulfil certain criteria, namely when they reach a sufficient level of quality and, most importantly, when they provide a sufficient guarantee in practice. ${ }^{81}$ The Court made it clear that it would subject the assurances in each case before it to a thorough examination and that it would take a pragmatic approach to them. In short, the Court will accept assurances only if they are reliable. Therefore, given that the assurances that are accepted by the Court are strikingly different from the assurances that were accepted by Sweden in the two notorious cases mentioned above, the Court cannot be accused of allowing diplomatic assurances to circumvent the absolute prohibition in Article 3 ECHR. By examining the jurisprudence of the Court in depth in the next section, it will become clear that the assurances that are accepted by the Court are indeed adequate guarantees of safety.

\footnotetext{
${ }^{77}$ Agiza (n 69) para 13.4.

${ }^{78}$ ibid.

${ }^{79}$ Alzery (n 69) para 11.5 .

80 ibid.

${ }^{81}$ Saadi (n 38) para 148.
} 


\section{EXAMINING THE STRASBOURG COURT'S CRITERIA FOR ASSESSING THE RELIABILITY OF ASSURANCES}

The Strasbourg Court assesses the reliability of assurances on a case-by-case basis and in light of all the circumstances of the case. It examines the quality of the assurances and, in particular, their scope and content. The Court takes a pragmatic approach as regards these assurances. It examines whether, in their practical application, they can provide effective protection against the risk of ill-treatment. In doing so, the Court takes into account a wide range of factors. This section will examine these factors in depth and will demonstrate that, as a result of its pragmatic approach, the Court has managed to accept only those assurances that are adequate guarantees of safety.

\section{Disclosure of the terms of the assurances to the Strasbourg Court}

The Strasbourg Court requires the Contracting States to disclose the terms of the assurances to the Court. ${ }^{82}$ This point is well-illustrated in the case of Muminov $v$ Russia, which concerned the expulsion of the applicant from Russia to Uzbekistan. ${ }^{83}$ In that case, although the respondent Government claimed that it had received assurances from the Uzbek authorities, given that the Government 'did not submit a copy of any diplomatic assurances indicating that the applicant would not be subjected to torture or ill-treatment', the Court held that his expulsion breached Article 3 ECHR. ${ }^{84}$ Therefore, in cases where the Contracting States do not disclose the terms of the assurances to the Court, the Court does not consider the assurances as a relevant factor in the assessment of the risk. ${ }^{85}$ The approach of the Court is to be applauded, as the Court has demonstrated that a Contracting State cannot satisfy its obligations under Article 3 ECHR by merely claiming that it received assurances from the authorities of the receiving State. The assurances need to be examined by the Court itself and they also need to fulfil the Court's criteria in order to be considered as adequate guarantees of safety.

\section{Specific and explicit guarantees}

In examining the quality of the assurances given, the Strasbourg Court takes into account the content of the assurances. ${ }^{86}$ The Court in Saadi and other cases has raised the lack of specific

\footnotetext{
${ }^{82}$ Othman (n 29) para 189.

${ }^{83}$ Muminov v Russia App no 42502/06 (ECtHR, 11 December 2008) para 34.

${ }^{84}$ ibid paras 97-98.

85 ibid.

${ }^{86}$ Othman (n 29) para 189.
} 
Are Diplomatic Assurances Adequate Guarantees of Safety Against Torture and IllTreatment? The Pragmatic Approach of the Strasbourg Court

and explicit guarantees as a ground for rejecting the assurances ${ }^{87}$ For example, in the case of Khaydarov $v$ Russia that concerned planned extradition from Russia to Tajikistan, the Court found the letters of the Tajikistani authorities to be insufficient as they 'contained no reference whatsoever to the protection of the applicant from treatment proscribed by Article 3 of the Convention'. ${ }^{88}$ Thus, they were rejected by the Court as they lacked explicit and specific guarantees against the subjection of the applicant to the proscribed treatment. In contrast, the Court in the case of Othman found that the Memorandum of Understanding (MoU) agreed between the United Kingdom Government and the Jordanian Government that provided, inter alia, that '[i]f arrested, detained or imprisoned following his return, a returned person (...) will be treated in a humane and proper manner, in accordance with internationally accepted standards', was specific and comprehensive. ${ }^{89}$ Given that the MoU addressed 'directly the protection of the applicant's Convention rights in Jordan', it was not rejected by the Court. ${ }^{90}$

Although the Strasbourg Court in Saadi made it clear that even the existence of specific and explicit assurances on their own would not be sufficient to ensure adequate protection against the risk of torture and other ill-treatment, the Court seems to attach weight to the scope and content of the assurances. Even though the practical effect of the assurances is more important than their content, assurances which lack explicit and specific guarantees against the subjection of the applicant to the proscribed treatment are rejected by the Strasbourg Court. Thus, although this factor may be of limited significance as regards the extent to which the assurances can be relied upon, the Strasbourg Court insists on seeking specific and explicit guarantees.

\section{Legality of treatment}

A further factor considered by the Court is whether the assurances concern treatment in the receiving State that is legal or illegal. ${ }^{91}$ The case of Einhorn v France is illustrative of this point. ${ }^{92}$ This case concerned the extradition of an individual convicted of murder from France to the United States of America. ${ }^{93}$ France obtained assurances from the authorities of the United States of America that the applicant would not be sentenced to death and therefore would not be subjected to treatment contrary to Article 3 ECHR through exposure to the

\footnotetext{
${ }^{87}$ Saadi (n 38) para 147; Khaydarov v Russia App no 21055/09 (ECtHR, 20 May 2010) para 111.

${ }^{88}$ Khaydarov (n 87) paras 18, 111.

${ }^{89}$ Othman (n 29) paras 77, 194.

90 ibid para 194.

91 ibid para 189.

${ }^{92}$ Einhorn v France (dec) App no 71555/01 (ECtHR, 16 October 2001).

93 ibid paras 2, 10.
} 
'death-row phenomenon'. ${ }^{94}$ The Court, in assessing whether the assurances were sufficient to avert the risk of the death penalty being imposed, paid due regard to the fact that the imposition of the death penalty was not merely prohibited by the assurances themselves but that it was also prohibited by law. ${ }^{95}$ In this case, the offence of which the applicant stood accused was committed before a statute restoring the death penalty in the particular federal State came into force. ${ }^{96}$ Given that Article 1 of the United States Constitution provided that a federal State must not pass an ex post facto law and given that the United States Supreme Court held that a federal State must not 'retrospectively impose a heavier penalty than was applicable at the time when the offence was committed', the Court held that the assurances were sufficient to avert the risk as they guaranteed that which was also prohibited by law. ${ }^{97}$

What emerges from the Strasbourg Court's approach in the case of Einhorn is that when the assurances guarantee the protection of the applicant from treatment that is in the receiving State illegal, they will be deemed as sufficient guarantees of safety. Where the law itself protects the applicant from subjection to the proscribed treatment, the assurances constitute an additional safeguard against such treatment. Therefore, the approach of the Court in accepting the assurances as adequate guarantees of safety in this context is reasonable and justified, given that a State that gives assurances not to do something which is also prohibited by law must uphold its promise.

\section{The position and the authority of the provider of the assurances and Contracting States as providers of the assurances}

In assessing the practical effect of the assurances, the Strasbourg Court takes into account the position and the authority of the provider of the assurances. ${ }^{98}$ The case of Baysakov and others $v$ Ukraine illustrates this. ${ }^{99}$ In that case it was the First Deputy General Prosecutor of the Republic of Kazakhstan who sent to the Ukrainian authorities assurances that the applicants, if extradited to Kazakhstan, would not be subjected to ill-treatment. ${ }^{100}$ The Court found that the assurances were unreliable as it was not established that the First Deputy Prosecutor General of Kazakhstan or the institution which he represented was empowered to provide such assurances on behalf of the State'. ${ }^{101}$ By contrast, in Othman, the Court found

\footnotetext{
94 ibid para 24.

95 ibid para 26.

96 ibid.

97 ibid para 26.

98 Othman (n 29) para 189.

${ }^{99}$ Baysakov and others $v$ Ukraine App no 54131/08 (ECtHR, 18 February 2010).

100 ibid para 15.

101 ibid para 51.
} 
Are Diplomatic Assurances Adequate Guarantees of Safety Against Torture and IllTreatment? The Pragmatic Approach of the Strasbourg Court

that the MoU concluded between the United Kingdom Government and the Jordanian Government was sufficient to remove any real risk of ill-treatment, given that it had been approved and supported by high-level officials of the Jordanian Government and by the King himself. ${ }^{102}$ Thus, the assurances were accepted as adequate guarantees in this case because they had been given by officials who were 'capable of binding the Jordanian State'. ${ }^{103}$

It is clear therefore that the Court accepts assurances as adequate and reliable guarantees only when they are given by high-level officials who are capable of binding the receiving State. However, one may argue that even if they are given by such persons, diplomatic assurances are not legally binding and thus, the receiving State would not have to abide by them. ${ }^{104}$ Similarly, opponents of the diplomatic assurances policy argue that assurances are unreliable on the basis that they are given by States which breach their legally binding human rights obligations and would therefore fail to comply with their non-legally binding assurances. ${ }^{105}$ Such an argument was raised by a judge in the Canadian case of Lai Cheong Sing and others $v$ the Minister of Citizenship and Immigration, who questioned whether a State which is 'not prepared to respect a higher legal instrument that it has signed and ratified (...) would (...) respect a lower-level instrument such as a diplomatic note'. ${ }^{106}$ This was also one of the arguments that Othman raised in supporting his case before the Strasbourg Court. ${ }^{107}$

Although assurances are usually given by States that breach their legally binding human rights obligations, it does not always follow that these States would also breach their non-legally binding assurances. This is because 'diplomatic assurances may hold incentives for states to respect the promise given different from those connected to respecting their commitments in international human rights law'. ${ }^{108}$ Even though diplomatic assurances impose less than a legal obligation, the State that gives the assurances would be more careful not to break its word in this context, given that its reputation as a bilateral collaborator would be seriously damaged in the case of breach and it also risks harming its diplomatic relations with the other State in issue. ${ }^{109}$ A negative impact on diplomatic relations, in turn, 'may bring

\footnotetext{
102 Othman (n 29) para 195.

103 ibid.

104 Skoglund (n 74) 335.

105 Jones (n 68) 188.

${ }^{106}$ Lai Cheong Sing and others $v$ the Minister of Citizenship and Immigration 2007 FC 361 (Can) para 147.

107 Othman (n 29) para 193.

108 Skoglund (n 74) 353, 355.

109 ibid 355.
} 
economic and political consequences beyond those of a poor human rights record, and this threat is what can bring leverage to diplomatic assurances'. ${ }^{110}$

Therefore, although diplomatic assurances are not legally binding and are often given by States that breach their legally binding human rights obligations, it does not follow that they are ineffective. They are given in a highly political context that makes States careful to uphold their promises, often making them reliable. In Othman the assurances were approved by the King himself and were provided by a Government 'whose bilateral relations with the United Kingdom have, historically, been very strong'. ${ }^{111}$ As such, the Jordanian authorities would likely be more careful to ensure Othman's proper treatment as his subjection to illtreatment would have a negative impact on Jordan's relationship with the United Kingdom. ${ }^{112}$ For these reasons, the Court accepted the assurances as adequate guarantees, even though the 'status of the MoU in Jordanian law' was unclear. ${ }^{113}$ However, in cases such as Baysakov, where the assurances are given by individuals who are not capable of binding the receiving State, the assurances are correctly rejected by the Court. Given that such individuals do not have any interest in ensuring the enforcement of the assurances, the assurances are essentially empty promises.

The Strasbourg Court adopts the same approach and accepts assurances as adequate guarantees of safety when they are given by a Member State of the Council of Europe and a Contracting Party to the Convention. ${ }^{114}$ This approach by the Court is correct given that a Member State of the Council of Europe and a Contracting State to the ECHR would be careful to uphold its promise on the ground that 'a possible failure to respect such assurances would seriously undermine that State's credibility'. ${ }^{115}$ Thus, this is another important factor in the assessment of the reliability of assurances. According to the Court, therefore, it is the political context in which the assurances are given that makes those assurances reliable.

\section{Acceptance of assurances by local authorities}

By examining the above-mentioned cases of Baysakov and Othman, it has been made clear that the Court accepts assurances as adequate guarantees only when given by high-level officials who are capable of binding the receiving State. However, even if the assurances are given by high-level officials or by the central Government itself, it has to be further shown

\footnotetext{
110 ibid.

111 ibid para 195.

112 ibid para 196.

113 ibid para 195.

${ }^{114}$ Chentiev and Ibragimov v Slovakia (dec) App nos 21022/08 and 51946/08 (ECtHR, 14 September 2010$) 15$.

115 ibid.
} 
Are Diplomatic Assurances Adequate Guarantees of Safety Against Torture and IllTreatment? The Pragmatic Approach of the Strasbourg Court

that the local authorities are expected to abide by them. ${ }^{116}$ This point is well-illustrated in the case of Chahal $v$ the United Kingdom which concerned the planned expulsion of Chahal from the United Kingdom to India on grounds of national security. ${ }^{117}$

Although the assurances in this case had been given by the Indian Government itself, the Court found that they were unreliable as it was clear that the Indian security forces were not expected to abide by them. ${ }^{118}$ Although the Court did not 'doubt the good faith of the Indian Government in providing the assurances', given that the violation of human rights by certain members of the security forces in Punjab and elsewhere in India was 'a recalcitrant and enduring problem', the Court was not persuaded that the assurances in issue 'would provide Mr Chahal with an adequate guarantee of safety'. ${ }^{119}$ This, however, was not the case in Othman. In the case of Othman the risk of ill-treatment emanated from the Jordanian General Intelligence Directorate (GID). ${ }^{120}$ The Court in that case held that the assurances were sufficient to remove the risk of ill-treatment, as senior officials of the GID, from where the risk of ill-treatment emanated, approved and supported the assurances. ${ }^{121}$

By accepting assurances as adequate guarantees only in circumstances in which the local authorities, in particular the security forces, are expected to abide by them, the Court has demonstrated its insistence on the 'practical effect' criterion and it has managed to discharge the often-raised criticism that assurances are unreliable because they will not 'affect the behaviour of out-of-control security forces'. ${ }^{122}$ The Court in the case of Chahal made clear that even if the assurances are given by high-level officials or by the Government itself, if in practical terms they do not eliminate the risk of ill-treatment, they will be deemed inadequate. Given that the assurances in Chahal were basically empty promises, as the security forces from where the risk of ill-treatment emanated were not expected to abide by them, the Court was right in rejecting them. ${ }^{123}$ In contrast, given that the risk in the case of Othman emanated from the GID and senior officials of the GID approved and supported the assurances, the Court was right in accepting them as adequate guarantees. ${ }^{124}$

\footnotetext{
${ }^{116}$ Othman (n 29) para 189.

${ }^{117}$ Chahal (n 1) para 25.

118 ibid paras 37, 105.

119 ibid para 105.

120 Othman (n 29) paras 191-192.

121 ibid para 195.

122 Jones (n 68) 190.

${ }^{123}$ Chahal (n 1) para 105.

${ }^{124}$ Othman (n 29) para 195.
} 


\section{The bilateral relations of the two States and the receiving State's record in abiding}

\section{by similar assurances}

As has been already mentioned in relation to Othman, the Court, in examining the practical effect of the MoU concluded between the United Kingdom Government and the Jordanian Government, took account of the fact that the assurances had been given by a Government 'whose bilateral relations with the United Kingdom have, historically, been very strong'. ${ }^{125}$ The Court considered this factor again in Al-Moayad v Germany, a case that concerned the extradition of the applicant from Germany to the United States of America to face terrorismrelated charges. ${ }^{126}$ The applicant was extradited under the condition that he would not be detained in a facility outside the United States of America where the interrogation methods were contrary to Article 3 ECHR. ${ }^{127}$ The Court found that the assurances at issue were sufficient to avert the danger of subjection to interrogation methods proscribed by Article 3 ECHR. ${ }^{128}$ In doing so, the Court focused on the length and strength of bilateral relations between the two States and the United States' record in abiding by similar assurances. ${ }^{129}$ Given that Germany had carried out a number of extraditions to the United States of America in reliance on assurances that it had found to be respected in practice, such assurances were found by the Court to be sufficient. ${ }^{130}$

As noted, opponents of the diplomatic assurances policy often contend that assurances are given by States which are 'known to torture' and are therefore unreliable. ${ }^{131}$ The United States, for example, which provided assurances in Al-Moayad, does not have 'an entirely positive human rights record', according to Alice Izumo. ${ }^{132}$ It does not however follow that in the particular circumstances of the case the assurances given by them could not be relied upon. Even though the United States' human rights record might not be entirely positive, the Court determined that the assurances given by them would be respected in this particular case. The Court's approach, which focuses on the context in which the assurances are given, seeks to ensure compliance. Given that Germany's relationship with the United States had been strong in this context and given also that assurances had been respected by the relevant authorities in all extradition cases, the assurances given by them in this case could be relied

\footnotetext{
125 ibid.

${ }^{126}$ Al-Moayad v Germany (dec) App no 35865/03 (ECtHR, 20 February 2007) paras 6, 24.

127 ibid paras 13,21 .

128 ibid paras 67-68.

129 ibid para 68.

130 ibid.

${ }^{131}$ Katherine R Hawkins, 'The Promises of Torturers: Diplomatic Assurances and the Legality of "Rendition"” (2006) 20 Geo Immigr LJ 213, 268.

132 Izumo (n 42) 270.
} 
Are Diplomatic Assurances Adequate Guarantees of Safety Against Torture and IllTreatment? The Pragmatic Approach of the Strasbourg Court

upon. Thus, although the assurances are usually given by States that may be criticised regarding their human rights record, the Court assesses the likelihood of compliance by looking at the context in which they are given.

\section{Examination of the assurances by domestic courts}

The Court in the case of Al-Moayad, in assessing the reliability of the assurances, also gave weight to the fact that the assurances had been examined by the German courts. ${ }^{133}$ The German courts examined the assurances given by the United States of America and concluded that they could be relied upon. ${ }^{134}$ This was taken into account by the Strasbourg Court. ${ }^{135}$ Similarly, in the case of Othman, the Court paid due regard to the fact that the assurances in issue 'withstood the extensive examination' which had been carried out by an independent and domestic tribunal, being the Special Immigration Appeals Commission. ${ }^{136}$ One may argue that the Court should not give any weight to the assessments carried out by the domestic courts of the sending Contracting States, given that the domestic courts may fail to make an objective assessment in their enthusiasm for deportations and deportations with assurances policy. ${ }^{137}$ However, given that the Court does not rely solely on the assessments carried out by the domestic courts of the sending Contracting States and examines the assurances itself, the assurances that are accepted as adequate guarantees are those which withstood the Court's examination and which fulfilled the Court's criteria for reliability.

\section{Previous ill-treatment}

A further factor considered by the Court in assessing the practical effect of the assurances is whether the applicant had previously been ill-treated in the receiving State. ${ }^{138}$ The case of Koktysh v Ukraine, which concerned the planned extradition of the applicant from Ukraine to Belarus, demonstrates this. ${ }^{139}$ Although the authorities of Belarus gave assurances to the Ukrainian authorities that the applicant would not be tortured or ill-treated upon return to Belarus, the Court found that his extradition, if implemented, would constitute a breach of Article 3 ECHR. ${ }^{140}$ Given that the applicant had been previously ill-treated by the Belarusian authorities, the Court held that the assurances would not suffice to guarantee against the serious risk of ill-treatment, concluding that his extradition, if implemented, would constitute

\footnotetext{
${ }^{133}$ Al-Moayad (n 126) para 66.

134 ibid.

135 ibid.

136 Othman (n 29) para 194.

137 Jones (n 68) 193.

${ }^{138}$ Othman (n 29) para 189.

${ }^{139}$ Koktysh v Ukraine App no 43707/07 (ECtHR, 10 December 2009) para 16.

140 ibid paras 19, 65.
} 
a breach of Article 3 ECHR. ${ }^{141}$ The approach of the Court in this case is to be applauded as it demonstrates once again that even if the assurances are explicit and specific, as in the case of Koktysh, they would not be accepted as adequate guarantees against the risk of ill-treatment if, in practical terms based on past experiences, they are not sufficient to avert such risk. ${ }^{142}$

\section{Effective system of torture prevention in the receiving State and engagement with human rights}

The Court will also consider whether there is an effective system of torture prevention in the receiving State, including whether it is willing to investigate allegations of torture and to punish those responsible and whether it is willing to co-operate with international monitoring mechanisms and Non-Governmental Organisations (NGOs). ${ }^{143}$ For example, the Court in the case of Soldatenko v Ukraine raised the lack of international co-operation of the Turkmen authorities in the field of human rights, as well as the lack of an effective system of torture prevention in Turkmenistan, as grounds for rejecting the assurances given by them. ${ }^{144}$ In doing so, the Court paid heed to the report of the United Nations Secretary General in which he expressed concerns about the categorical denials of human rights violations by Turkmenistan despite consistent information from reliable sources and about the reluctance of Turkmenistan to co-operate with the United Nations treaty monitoring bodies and NGOs. ${ }^{145}$ In light of these difficulties, the Court correctly concluded that it would be difficult to see whether such assurances would have been respected. ${ }^{146}$ The Court was therefore right in rejecting them.

\section{Post-transfer monitoring mechanisms}

The assurances in the case of Othman were accepted by the Court as adequate guarantees partly due to the fact that they provided for monitoring mechanisms that could ensure and verify compliance with them. ${ }^{147}$ The Court, in concluding that the Adaleh Centre (a human rights organisation based in Jordan) was capable of verifying compliance with the assurances, took account of the fact that the Centre was independent from the Jordanian Government, as it was mainly funded by the government of the United Kingdom, and also of the fact that the Centre would have full access to Othman in prison for as long as he remained there. ${ }^{148}$ Even

\footnotetext{
141 ibid paras 64-65.

142 ibid paras 19,64 .

143 Othman (n 29) para 189.

${ }^{144}$ Soldatenko v Ukraine App no 2440/07 (ECtHR, 23 October 2008) para 73.

145 ibid paras 36,73 .

146 ibid para 73.

${ }^{147}$ Othman (n 29) para 196.

148 ibid paras 202-204.
} 
Are Diplomatic Assurances Adequate Guarantees of Safety Against Torture and IllTreatment? The Pragmatic Approach of the Strasbourg Court

though the nature of torture makes compliance with assurances more difficult, the Court, by accepting assurances as adequate guarantees only when there are monitoring mechanisms in place that are capable of ensuring compliance with them, has managed to discharge this criticism as regards the assurances that it accepts as adequate guarantees. For example, given that in Othman the Adaleh Centre could ensure Othman's proper treatment by having full access to Othman in prison, the assurances were adequate guarantees. ${ }^{149}$

Jeffrey $G$ Johnston has doubted the effectiveness of post-transfer monitoring in ensuring and verifying compliance with assurances against torture. ${ }^{150}$ In particular, he has contended that post-transfer monitoring is ineffective, given that torture is not 'easy to detect'. ${ }^{151}$ Whilst this may be true, the assurances that are accepted by the Court are reliable because the monitoring mechanisms are subjected to a thorough examination by the Court. The effectiveness of the Adaleh Centre, for example, had been examined by the Court before concluding that it could ensure and verify compliance with the assurances. Key was the fact that its personnel would have full access to Othman for as long as he remained in detention. ${ }^{152}$ Therefore, although assurances may be unreliable in some cases due to the ineffectiveness of post-transfer monitoring mechanisms, Johnston's argument is not valid per se as regards the assurances accepted by the Court as adequate guarantees.

\section{Human rights situation in the receiving State}

As has already been explained, the Court in the case of Saadi held that the assurances given by the Tunisian authorities were unreliable, as, in practice, they could not eliminate the risk of ill-treatment, given the widespread use of torture in Tunisia. ${ }^{153}$ Even though the Court has stated that 'it will only be in rare cases that the general situation in a country will mean that no weight at all can be given to assurances', the Court in a number of cases since Saadi has given no weight at all to assurances from States where torture was endemic or persistent. ${ }^{154}$ The Court in three similar cases found that the human rights situation in the receiving State excluded accepting any assurances whatsoever. In Sultanov v Russia, Yuldashev v Russia and Ismoilov and others $v$ Russia that all concerned planned extraditions from Russia to Uzbekistan, the Court gave no weight at all to the assurances given by the Uzbek

\footnotetext{
149 ibid para 202.

${ }^{150}$ Jeffrey G Johnston, 'The Risk of Torture as a Basis for Refusing Extradition and the Use of Diplomatic Assurances to Protect against Torture After 9/11' (2011) 11 ICLR 1, 23.

151 ibid.

152 Othman (n 29) para 202.

153 Saadi (n 38) para 147.

${ }^{154}$ Othman (n 29) para 188; Yuldashev v Russia App no 1248/09 (ECtHR, 8 July 2010) para 85; Sultanov v Russia App no 15303/09 (ECtHR, 4 November 2010) para 73; Ismoilov and others v Russia App no 2947/06 (ECtHR, 24 April 2008) para 127; Gaforov (n 25) para 138.
} 
authorities. ${ }^{155}$ Given that reliable sources described the practice of torture in Uzbekistan as systematic, the Court was not 'persuaded that assurances from the Uzbek authorities offer a reliable guarantee against the risk of ill-treatment'. ${ }^{156}$

The human rights reputation of the receiving State is, in some cases, a determinative factor for accepting the assurances, rather than for rejecting them. The human rights reputation of the United States, for example, was one of the factors that led the Court to conclude in the admissibility case of Babar Ahmad and others $v$ the United Kingdom that the assurances at issue could be relied upon. ${ }^{157}$ The case concerned the planned extradition of individuals suspected of being involved in terrorism-related crimes from the United Kingdom to the United States of America. ${ }^{158}$ The Court, in considering the assurances given, accorded a presumption of good faith to the United States Government. ${ }^{159}$ The Court noted that this good faith presumption arose out of the United States' positive human rights record, given that it had a 'long history of respect for democracy, human rights and the rule of law'. ${ }^{160}$ As a result, the Court held that the applicants' contention that the authorities of the United States of America might designate them enemy combatants in breach of their assurances was inadmissible. ${ }^{161}$

The cases of Sultanov, Yuldashev and Ismoilov demonstrate the Court's insistence on the 'practical effect' criterion. In cases where the assurances are given by States 'where torture is endemic or persistent', and the assurances are therefore insufficient to avert the serious risk of ill-treatment, the Strasbourg Court has made it clear that they would not be accepted as adequate guarantees. ${ }^{162}$ In contrast, given that the assurances in the case of Babar Ahmad were obtained from the United States of America which, according to the Court, maintains a positive human rights record, they were accepted as adequate guarantees. ${ }^{163}$ Thus, the often-raised criticism that assurances are unreliable because they are given by States which are 'known to torture' is not valid in the case of the Strasbourg Court, as the Court does not accept assurances from States where torture is endemic or persistent. ${ }^{164}$

\footnotetext{
155 Sultanov (n 154) paras 16, 73; Yuldashev (n 154) paras 15, 85; Ismoilov (n 154) paras 72, 127.

${ }^{156}$ Sultanov (n 154) para 73; Yuldashev (n 154) para 85; Ismoilov (n 154) para 127.

${ }^{157}$ Babar Ahmad and others $v$ the United Kingdom (dec) App nos 24027/07, 11949/08 and 36742/08 (ECtHR, 6 July 2010) paras 105, 109 .

158 ibid para 4.

159 ibid para 105 .

160 ibid.

161 ibid paras 109-110.

162 Sultanov (n 154) para 73; Yuldashev (n 154) para 85; Ismoilov (n 154) para 127.

${ }^{163}$ Babar (n 157) para 105.

${ }^{164}$ Hawkins (n 131) 268.
} 
Are Diplomatic Assurances Adequate Guarantees of Safety Against Torture and IllTreatment? The Pragmatic Approach of the Strasbourg Court

\section{E. CONCLUSION}

This paper has examined the approach of the Strasbourg Court to diplomatic assurances against torture and other ill-treatment. It has been argued that although the diplomatic assurances policy has been criticised for circumventing the absolute prohibition of torture and other ill-treatment on the basis that diplomatic assurances are per se unreliable, the Strasbourg Court, as a result of its pragmatic approach, has accepted those assurances which are adequate guarantees of safety. The Court seeks to ensure that the assurances it accepts as sufficient guarantees will be respected in practice. It does this by examining the reliability of assurances on a case-by-case basis and in light of all the circumstances of the case. It assesses not only their content, but also factors which are external to the assurances, such as the human rights situation in the receiving State and such States' human rights practices. Furthermore, by examining such a wide range of factors, the Strasbourg Court has implicitly highlighted that assurances must be able to withstand its extensive examination in order to be accepted as adequate guarantees of safety. Therefore, the Court cannot be accused of circumventing the absolute prohibition to be found in Article 3 ECHR as it accepts only the assurances that can remove the risk of torture and ill-treatment in practice. In other words, the Strasbourg Court has kept faith with the absolute prohibition of Article 3 ECHR as a result of this pragmatic approach. This approach has also allowed Contracting States to protect their national security from criminal acts and in particular, from acts of terrorism, without breaching their Article 3 ECHR obligations. In this respect, it can be argued that its approach is effective. 